\title{
Retinoic acid receptor-related orphan receptor a reduces lipid droplets by upregulating neutral cholesterol ester hydrolase 1 in macrophages
}

Hiroshi Matsuoka ${ }^{1 *}$ (D), Riki Tokunaga ${ }^{1}$, Miyu Katayama ${ }^{1}$, Yuichiro Hosoda ${ }^{1}$, Kaoruko Miya $^{1}$, Kento Sumi ${ }^{1}$, Ami Ohishi ${ }^{1}$, Jun Kamishikiryo², Akiho Shima' and Akihiro Michihara'

\begin{abstract}
Background: Neutral cholesterol ester hydrolase 1 (NCEH1) catalyzes the hydrolysis of cholesterol ester (CE) in macrophages. Genetic ablation of NCEH1 promotes CE-laden macrophages and the development of atherosclerosis in mice. Dysregulation of NCEH1 levels is involved in the pathogenesis of multiple disorders including metabolic diseases and atherosclerosis; however, relatively little is known regarding the mechanisms regulating NCEH1. Retinoic acid receptor-related orphan receptor a (RORa)-deficient mice exhibit several phenotypes indicative of aberrant lipid metabolism, including dyslipidemia and increased susceptibility to atherosclerosis.

Results: In this study, inhibition of lipid droplet formation by RORa positively regulated NCEH1 expression in macrophages. In mammals, the NCEH1 promoter region was found to harbor putative RORa response elements (ROREs). Electrophoretic mobility shift, chromatin immunoprecipitation, and luciferase reporter assays showed that RORa binds and responds to ROREs in human NCEH1. Moreover, NCEH1 was upregulated through RORa via a phorbol myristate acetate-dependent mechanism during macrophage differentiation from THP1 cells. siRNAmediated knockdown of RORa significantly downregulated NCEH1 expression and accumulated lipid droplets in human hepatoma cells. In contrast, NCEH1 expression and removal of lipid droplets were induced by RORa agonist treatments and RORa overexpression in macrophages.
\end{abstract}

Conclusion: These data strongly suggested that NCEH1 is a direct RORa target, defining potential new roles for RORa in the inhibition of lipid droplet formation through NCEH1.

Keywords: Atherosclerosis, Cholesterol metabolism, Lipid droplets, Macrophages, NCEH1, RORa, Transcriptional regulation

\footnotetext{
* Correspondence: matsuoka@fukuyama-u.ac.jp

'Laboratory of Genome Function and Pathophysiology, Faculty of Pharmacy

and Pharmaceutical Sciences, Fukuyama University, Fukuyama, Hiroshima

729-0292, Japan

Full list of author information is available at the end of the article
}

(c) The Author(s). 2020 Open Access This article is licensed under a Creative Commons Attribution 4.0 International License, which permits use, sharing, adaptation, distribution and reproduction in any medium or format, as long as you give appropriate credit to the original author(s) and the source, provide a link to the Creative Commons licence, and indicate if changes were made. The images or other third party material in this article are included in the article's Creative Commons licence, unless indicated otherwise in a credit line to the material. If material is not included in the article's Creative Commons licence and your intended use is not permitted by statutory regulation or exceeds the permitted use, you will need to obtain permission directly from the copyright holder. To view a copy of this licence, visit http://creativecommons.org/licenses/by/4.0/ The Creative Commons Public Domain Dedication waiver (http://creativecommons.org/publicdomain/zero/1.0/) applies to the data made available in this article, unless otherwise stated in a credit line to the data. 


\section{Background}

Neutral cholesterol ester hydrolase 1 (NCEH1), also known as KIAA1363 or arylacetamide deacetylase-like 1, is a key enzyme that suppresses lipid droplet formation by removing cholesterol from macrophage foam cells [1, 2]. In contrast, the ablation of NCEH1 accelerates atherosclerosis by promoting the formation of macrophage foam cells $[3,4]$. In addition to cholesterol uptake, the balance of free cholesterol (FC) and cholesterol esters (CEs) is also critical for the regulation of intracellular cholesterol content in macrophage foam cells. After internalization, lipoproteins are localized to late endosomes/lysosomes, where CEs are hydrolyzed into FC by lysosomal acid lipase. To prevent FC release, it is reesterified on the endoplasmic reticulum by acetyl-CoA acetyltransferase 1 and stored in cytoplasmic lipid droplets. If this pathway is persistently activated, excessive CEs will accumulate in macrophages, thereby resulting in the formation of foam cells. The resulting CEs are hydrolyzed by NCEH1 to release FC for transportermediated efflux, which is increasingly recognized as the rate-limiting step in FC outflow [5, 6].

Macrophage-specific overexpression of NCEH1 leads to a significant reduction in atherosclerotic lesions in low-density lipoprotein receptor (LDLR) ${ }^{-/-}$mice because of enhanced FC efflux and reverse cholesterol transport [3]. NCEH1 enzymatic activity was also shown to be regulated by polyunsaturated fatty acids [7] and paraoxon [8]. NCEH1 expression, which is robust in macrophages and atherosclerotic lesions, has been shown to be regulated by insulin [9] and interleukin (IL)-33 [10]. Moreover, NCEH1 transcripts are downregulated in cortical homogenates from peroxisome proliferator-activated receptor $\gamma$ coactivator 1- $\alpha$ (PGC-1 $\alpha)$-knockout mice and increased by PGC-1 overexpression [11]. However, the specific mechanisms through which transcriptional regulators modulate NCEH1 expression are still unclear. Notably, two putative response elements for retinoic acid receptor-related orphan receptor $\alpha(\mathrm{ROR} \alpha)$ are found at - 1451/- 1440 and -132/- 121 regions upstream of the transcription start site (TSS) in the NCEH1 gene.

The ROR $\alpha$ gene encodes a ligand-dependent orphan nuclear receptor that acts as a transcriptional regulator and has been identified as a novel anti-atherosclerosis target gene. ROR $\alpha$ regulates target gene expression mainly by binding as monomers to promoter response elements, which typically consist of a consensus AGGTCA half-site preceded by an A/T-rich sequence (ROR response elements [ROREs]) [12]. ROR $\alpha$ is constitutively active, meaning that the protein remains in an active conformation in the absence of ligand and that ligand binding can actually suppress receptor activity. Although endogenous ligands of $\mathrm{ROR} \alpha$ have not yet been fully elucidated, recent evidence suggests that oxygenated sterols might function as high-affinity ligands. Indeed, 7-oxygenated sterols (e.g. $7 \alpha-\mathrm{OHC}, 7 \beta-$ $\mathrm{OHC}$, and 7-ketocholesterol), 24-hydroxycholesterol (24-OHC), and 25-hydroxycholesterol (25-OHC) function as inverse agonists for $\operatorname{ROR} \alpha[13,14]$. ROR $\alpha$ deficient mice harboring a natural deletion in the ligandbinding domain exhibit cerebellar ataxia, a phenotype also observed in Staggerer (sg/sg) mutant mice [15], which express mutated ROR $\alpha$ and present with vascular dysfunction, dyslipidemia, excessive inflammation, immune abnormalities, and diet-induced atherosclerosis [16-18]. Recent studies have demonstrated decreases in serum and liver triglycerides and total and high-density lipoprotein serum cholesterol in $\mathrm{sg} / \mathrm{sg}$ mice. These mice also exhibit decreased hepatic expression of sterol regulatory element-binding transcription factor 1 (SREBP-1c) and the reverse cholesterol transporters ABCA1 and ABCG1 [19]. Moreover, ROR $\alpha$ positively regulates apolipoprotein A (APOA)-I and APOC-III, suggesting a role in lipid metabolism $[20,21]$. The transcriptional activator steroid receptor coactivator-2 (SRC-2) functions as a coactivator with $\mathrm{ROR} \alpha$ to modulate the expression of the essential gluconeogenesis genes glucose 6phosphatase (G6Pase) [22] and phosphoenolpyruvate carboxykinase (PEPCK) [23], the rate-limiting enzyme that controls glucose release into the plasma. Moreover, ROR $\alpha$ deficiency and treatment with ROR $\alpha$ inverse agonists inhibit PEPCK expression and glucose production in mice [24, 25]. Additionally, overexpression of RevErbo, the physiological inhibitor of ROR $\alpha$, suppresses the expression of gluconeogenesis genes in human liver cancer cell lines. Conversely, silencing Rev-Erb $\alpha$ significantly induces the expression of gluconeogenesis-related genes [26-28].

In brain endothelial cells, claudin domain containing 1 (CLDND1), which is involved in tight junction formation, is regulated at the transcriptional level by ROR $\alpha$ and at the post-transcriptional level by miR124 [29, 30]. Moreover, decreased CLDND1 expression in the adult murine cerebellum results in cerebellar hemorrhage [31].

In macrophages, using the CRISPR-Cas9 system, ROR $\alpha$ was deleted in human THP1 monocytic cells, and a dramatic increase was observed in the basal expression of a subset of nuclear factor (NF)- $\mathrm{kB}$-regulated antiinflammatory genes, including tumor necrosis factor, IL$1 \beta$, and IL- 6 , both at the transcriptional and translational levels [32]. ROR $\alpha$ is a negative regulator of the inflammatory response, functioning via $N F-\kappa B$ inhibition through $\mathrm{I}_{\kappa} \mathrm{B}$ activation [33]. Moreover, NF- $\mathrm{kB}$ activation requires the removal of $I \kappa B$ from NF- $\kappa B$ through inducible proteolysis, which liberates this transcription factor for migration to the nucleus, where it binds IкBregulatory elements and induces transcription [34]. 
As described, ROR $\alpha$ is involved in many physiological processes including the regulation of metabolism, development, immunity, and the circadian rhythm. The recent characterization of endogenous ligands for these former orphan nuclear receptors has stimulated the development of synthetic ligands and provided insights into targeting these receptors to treat several diseases including atherosclerosis, diabetes, autoimmunity, and cancer [14, 35, 36]. Nevertheless, the role of ROR $\alpha$ in modulating NCEH1 promoter activity is not clear. Accordingly, in this study, the role of ROR $\alpha$ in modulating NCEH1 expression was evaluated. The results suggested that the control of NCEH1 expression by synthetic ligands of ROR $\alpha$ might facilitate the development of novel antiarteriosclerosis drugs.

\section{Results}

\section{Identification of ROREs in the NCEH1 promoter}

Two putative response elements for ROR $\alpha$ were found at - 1451/- 1440 (RORE1) and - 132/- 121 (RORE2) regions upstream of the TSS in NCEH1 (Fig. 1a). The ROREs were found to contain a strongly conserved consensus sequence for ROR $\alpha$-binding sites based on analysis using the JASPER database (http://jaspar.genereg. net/) [37] (Fig. 1b). In particular, the consensus RGGTCA (R: A or G) half-site in NCEH1-ROREs was determined to be highly conserved in various mammals (Fig. 1c).

The ability of ROR $\alpha$ to bind its putative response element in the NCEH1 promoter was tested by electrophoretic mobility shift assays (EMSAs) and chromatin immunoprecipitation- polymerase chain reaction (ChIPPCR). To further identify the ROR $\alpha$-binding site in the NCEH1 gene, H3K27Ac ChIP-sequencing (ChIP-seq) and DNaseI hypersensitivity assays were used as mapping data with the UCSC Genome Browser (http://genome.ucsc.edu/) [38] (Fig. 1a). The location and sequence of this response element are shown in Fig. 1.

In addition to conventional EMSA, a 20-bp fragment spanning positions -132 to -121 and -1451 to - 1440 of the NCEH1 promoter was generated as a cold probe and competitor for hot probes, endlabeled similar to IKB, which contains a known RORE, and incubated with $R O R \alpha$ obtained by in vitro translation (Fig. 2a). ROR $\alpha$-depended sequence-specific mobility shifts were inhibited by the addition of excess unlabeled probe such as IKB and wild-type NCEH1-RORE (RORE1 as a weak binding site and RORE2 as a strong binding site), but not by mutant NCEH1-RORE. Additionally, anti-ROR $\alpha$ antibodies suppershifted as bound to the formation of the DNA-protein complex, suggesting that ROR $\alpha$ was present in the DNA-protein complex. In contrast, addition of anti-early growth response protein I (EgrI) antibodies as a negative control resulted in not bound to the DNA-protein complex, so ROR $\alpha$-depended binding manner (Fig. 2b).

To further validate the transactivation ability of ROR $\alpha$ at the NCEH1 promoter, ChIP assays were performed. The chromatin fragments of the NCEH1 promoter region from -1508 to -1257 and from -260 to -14 , containing the RORE1 and RORE2 sites, were immunoprecipitated by anti-ROR $\alpha$ antibodies (Fig. 2c). As a control, the addition of IgG alone did not result in immunoprecipitation of the chromatin fragment of the NCEH1 promoter (Fig. 2c). Additionally, quantitative PCR with ChIP samples revealed an increase of 1.2-fold in relative binding intensity to RORE1 in differentiated cells treated with phorbol 12-myristate 13-acetate (PMA) and an increase of 7.7-fold in binding intensity to RORE2 as compared to that in macrophages (data not shown).

\section{Characterization of ROREs in the NCEH1 promoter}

In HEK293 cells, luciferase reporter assays were utilized to assess the activity of the putative RORE1 and RORE2 in the NCEH1 promoter. We used the UCSC Genome Browser to identify distal, conserved, putative ROREs in the $5^{\prime}$ region of the NCEH1 gene, which contained a promoter located within a DNase I hypersensitivity site. ChIP-seq assays indicated that acetylation of lysine 27 in histone $\mathrm{H} 3$ might be involved in enhancing transcription (Fig. 1a and b). Luciferase expression after cotransfection of the ROR $\alpha$ expression plasmid with luciferase response plasmids containing three copies of the ROREs (pRORE1x3-wt, pRORE1x3-mt, pRORE2x3-wt, and pRORE2x3-mt) resulted in 0.93-, 1.00-, 1.80-, and 0.98 -fold activation, respectively, compared to that with the empty control vector (PGVP2) containing the SV40 promoter (Fig. 3a). Moreover, compared to the response of NCEH1-RORE, IкB-RORE, a known target gene of $R O R \alpha$, was found to increase 2.2-fold with two direct RORE repeats and to increase by 1.3 -fold with one RORE observed (data not shown). Furthermore, the region from -1689 to +128 of the $\mathrm{NCEH} 1$ gene was cloned into the luciferase reporter vector PGVB2 and transiently transfected into the human embryonic kidney cell line HEK293. Luciferase expression from pNCEH1 $(-1689 /+128)$, which contained two ROREs (RORE1 and RORE2), and pNCEH1 (- 140/+ 128)-wt was increased along with the transient overexpression of ROR $\alpha$ (Fig. 3b). In contrast, pRORE1x3-mt, pRORE2x3-mt, and pNCEH1(-140/+128)-mt were not activated. These results suggested that ROR $\alpha$ activates NCEH1 expression at the ROREs because a binding site was required in the NCEH1 promoter region. 


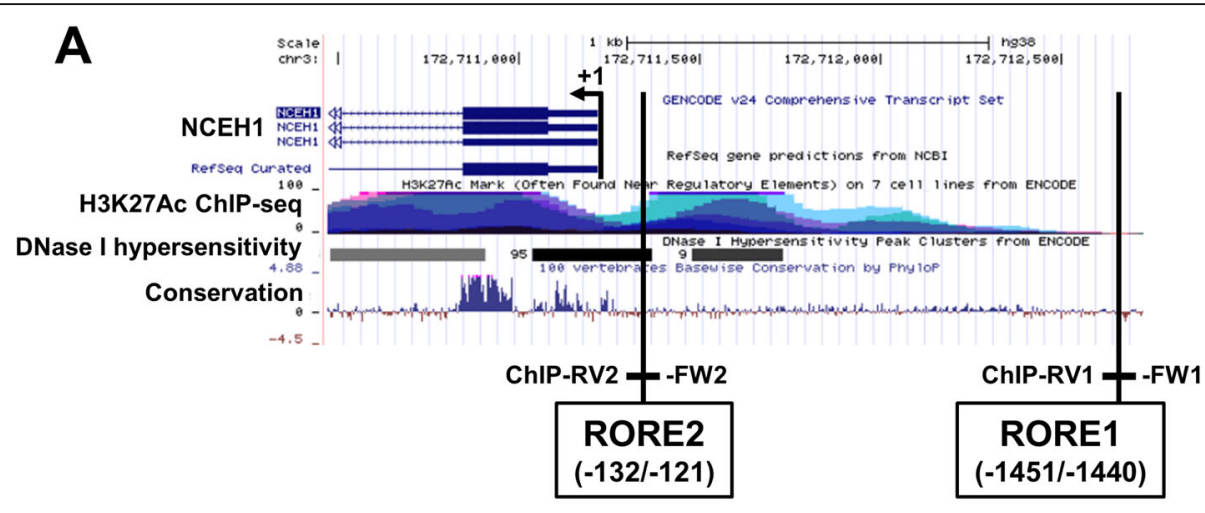

B

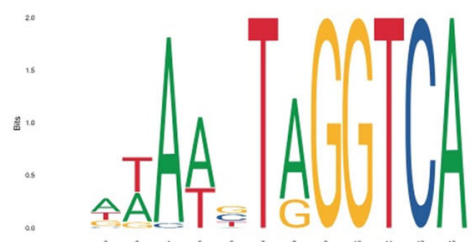

RORE consensus : DDMWBTRGGTCA

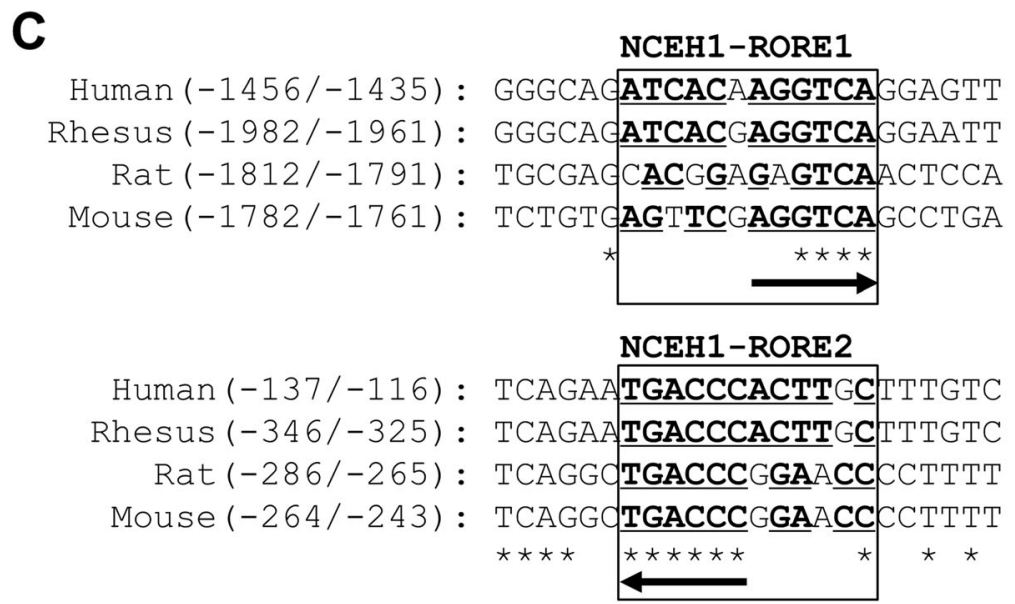

Fig. 1 RORa response elements in the NCEH1 promoter region. a The UCSC Genome Browser was used to identify distal, conserved, putative RORa response elements (ROREs) in the $5^{\prime}$ region of human NCEH1, which contained the promoter and was located within a DNase I hypersensitivity site. The positions of putative ROREs (RORE1 and RORE2) and transcription start site (TSS, +1 to position) are indicated by vertical lines. Chromatin immunoprecipitation (ChIP) assays were performed to amplify the ROREs using ChIP-FW1 and ChIP-RV1 or ChIP-FW2 and ChIPRV2 primer sets. Luciferase reporter constructs of the human NCEH1 promoter region were amplified by PCR using Promoter-FW (- 1689) and Promoter-RV (+ 128) primers. b The JASPAR tool was used to identify RORE consensus sequences (i.e. DDMWBTRGGTCA). RORE half-sites were found to be highly conserved regions, as indicated by arrows. c Schematic representation of putative ROREs in NCEH1 of various species aligned using ClustalW programs. The human sequence shown includes bases -1456 to -1435 as NCEH1-RORE1 and - 137 to -116 as NCEH1-RORE2 in the putative RORE region, which was tested using electrophoretic mobility shift assays (EMSAs) and reporter experiments. The nucleic acid sequence is shown, with RORE consensus sequences underlined and conserved sequences marked with asterisks in mammals. The direction of the RORE half-site is indicated by arrows

\section{RORa overexpression induces NCEH1 expression in HEK293 cells}

To examine whether NCEH1 expression increases with $\mathrm{ROR} \alpha$ expression, a transient $\mathrm{ROR} \alpha$ overexpression was carried out. Analyses were performed in HEK293 cells treated for $48 \mathrm{~h}$ with the $\mathrm{ROR} \alpha$ expression vector $(\mathrm{pROR} \alpha)$ or the vehicle vector (pSG5). The mRNA levels of ROR $\alpha$ were increased in HEK293 cells transfected with pROR $\alpha$ (Fig. 4a). Moreover, NCEH1 expression levels were increased following pROR $\alpha$ transfection (Fig. 4b). Additionally, the expression levels of BMAL1, as a positive control ROR $\alpha$-target gene, were increased (Fig. 4c). ROR $\alpha$ was found to positively regulate the expression of NCEH1 in HEK293 cells. 

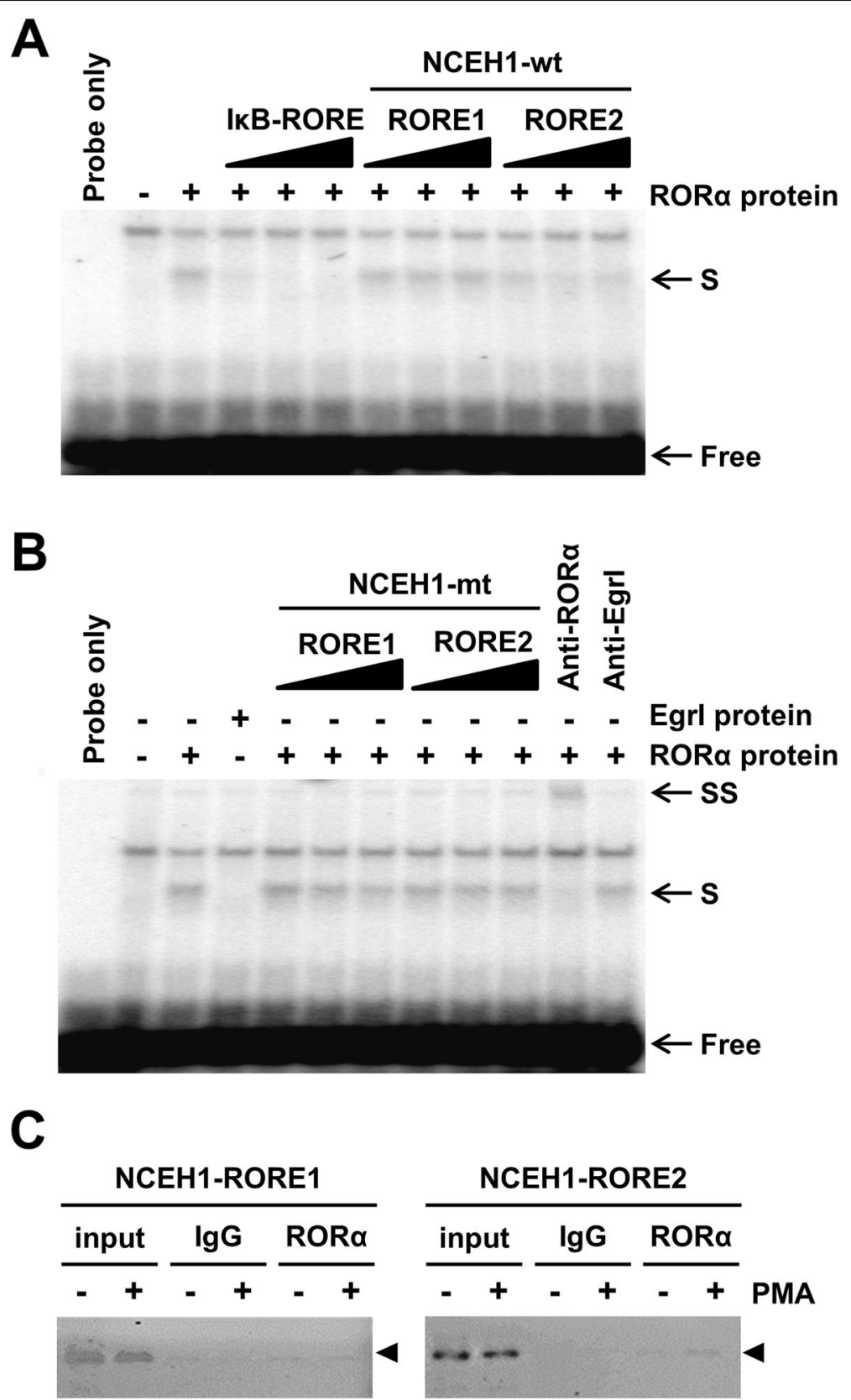

Fig. 2 RORa binds a putative response element in NCEH1. a Competition of unlabeled duplexes with the labelled IKB RORE probe for binding to in vitro-translated RORa proteins. The IKB probe contained the known RORa response element (RORE) for NF-kB inhibitor a. Reactions containing RORa proteins were carried out in the absence or presence of a 5-, 10-, and 20-fold molar excess of unlabeled duplexes as competitive probes (IKB-RORE, NCEH1-RORE1, and NCEH1-RORE2 [wild-type]). Shifted binding is indicated by S-arrows. The positions of free probes are indicated by free arrows. b Electrophoretic mobility shift assays (EMSAs) were used to test the ability of unlabeled mutated probes (5-, 10-, and 20-fold molar excess) to relieve the inhibition of binding of RORa to the putative response element (S-arrows). Anti-RORa antibodies were pre-incubated with RORa protein before adding the labeled probe for the formation of the super-shift band (SS-arrows). Negative control experiments were performed using Egrl protein and antibodies. Lane 1: labelled probe only; lane 2: reaction containing crude products from in vitro translation; lane 3: probe incubated with crude product obtained from in vitro translation in the absence of the RORa expression vector. c Chromatin immunoprecipitation (ChIP) assays were performed using chromatin isolated from human monocytes and differentiated macrophages treated with $100 \mathrm{nM}$ phorbol 12-myristate 13-acetate (PMA) for $24 \mathrm{~h}$. Crosslinked cell lysates were immunoprecipitated with rabbit lgG (IgG) or polyclonal anti-RORa-specific antibodies (RORa). DNA precipitates were isolated and then subjected to PCR using primer pairs covering either RORE1 or RORE2 of the NCEH1 promoter region. Control PCR was performed with non-immunoprecipitated genomic DNA (input) 

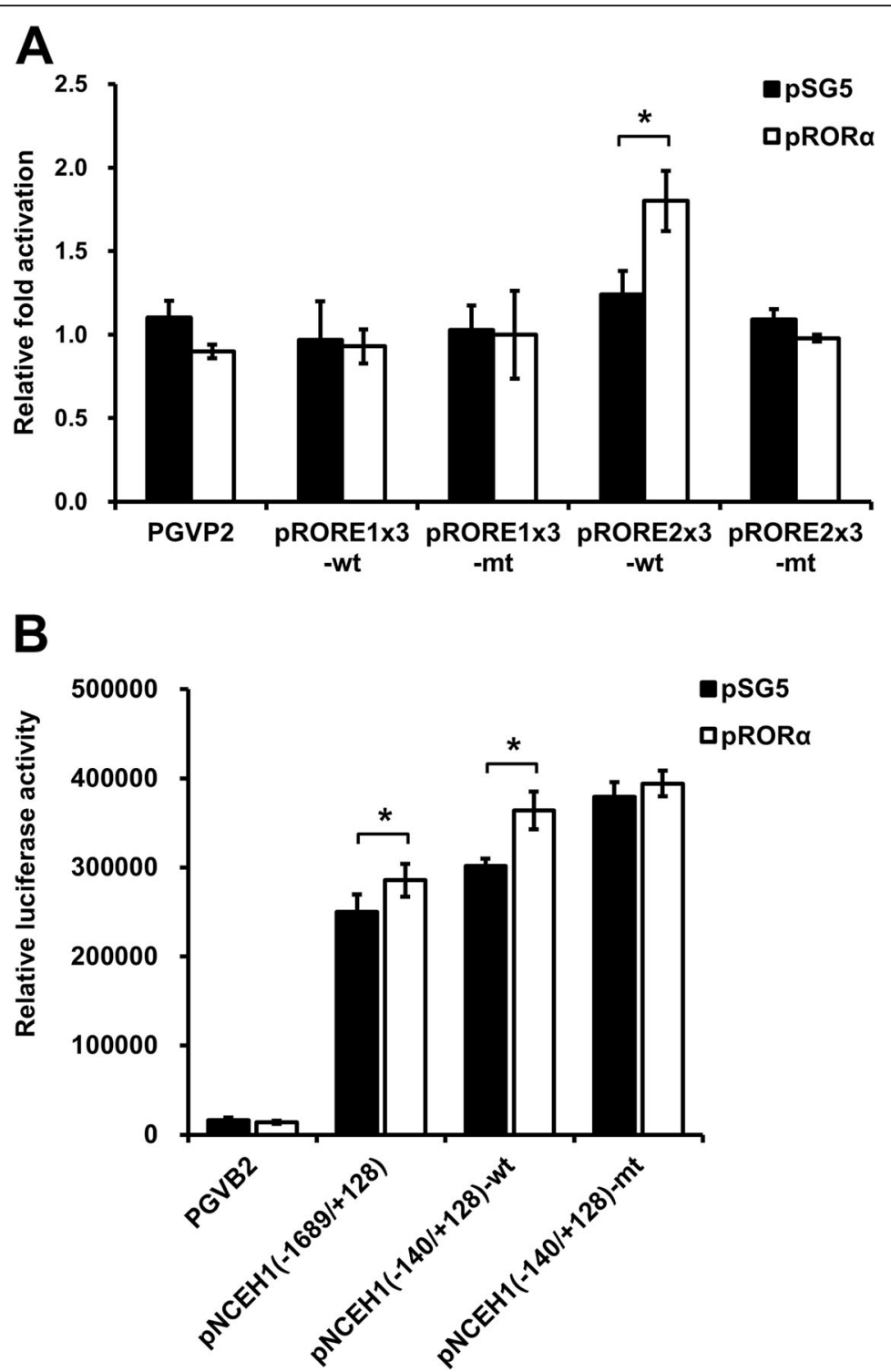

Fig. 3 RORa response elements (ROREs) of the NCEH1 promoter are directly activated by RORa. a HEK293 cells were transiently transfected with the luciferase reporter plasmid in the presence of pSV- $\beta$ gal. As a luciferase reporter plasmid, wild-type (wt) or mutant (mt) ROREs with three direct repeats, as found in the NCEH1 promoter region, were used. At $36 \mathrm{~h}$ after transfection, HEK293 cells were co-transfected without (pSG5) or with RORa expression vector (pRORa). Luciferase activity in the cell lysates was determined and expressed as fold-change in RORa activation based on luciferase activity. Data are means \pm standard errors $(n=4) .{ }^{*}, p<0.05$ versus PGVP2 control vector. $\mathbf{b}$ HEK293 cells were transfected without (pSG5) or with RORa expression vector (pRORa) plus luciferase-driven wild-type [pNCEH1(- 1689/+ 128) or pNCEH1 (- 140/+ 128)-wt] or mutant [pNCEH1 (- 140/+ 128)-mt] NCEH1 promoters. Mutations in the promoter included the mutation of RORE2. Data are fold-changes in transactivation relative to basal activity and are reported as means \pm standard errors $(n=4) .{ }^{*}, p<0.05$

RORa and NCEH1 expression increase in macrophages at both the mRNA and protein levels

In macrophages, ROR $\alpha$ increased the mRNA and the protein expression of NCEH1. To confirm this finding under our experimental conditions, THP1 cells were treated with 50 or 100 nM PMA to induce the differentiation of macrophages. Real-time PCR analysis showed that the expression of ROR $\alpha$ and NCEH1 were increased together with PMA induction in THP1 cells at $12 \mathrm{~h}$ (Fig. 5a and b). Similarly, western blot analysis showed that ROR $\alpha$ expression and NCEH1 protein expression were increased in THP1 cells at $24 \mathrm{~h}$ (Fig. 5e and f). Moreover, macrophage differentiation was monitored by measuring cluster of differentiation (CD) 11b and matrix metalloproteinase (MMP) 9 expression, as markers of macrophages (Fig. 5c and d). The results demonstrated 

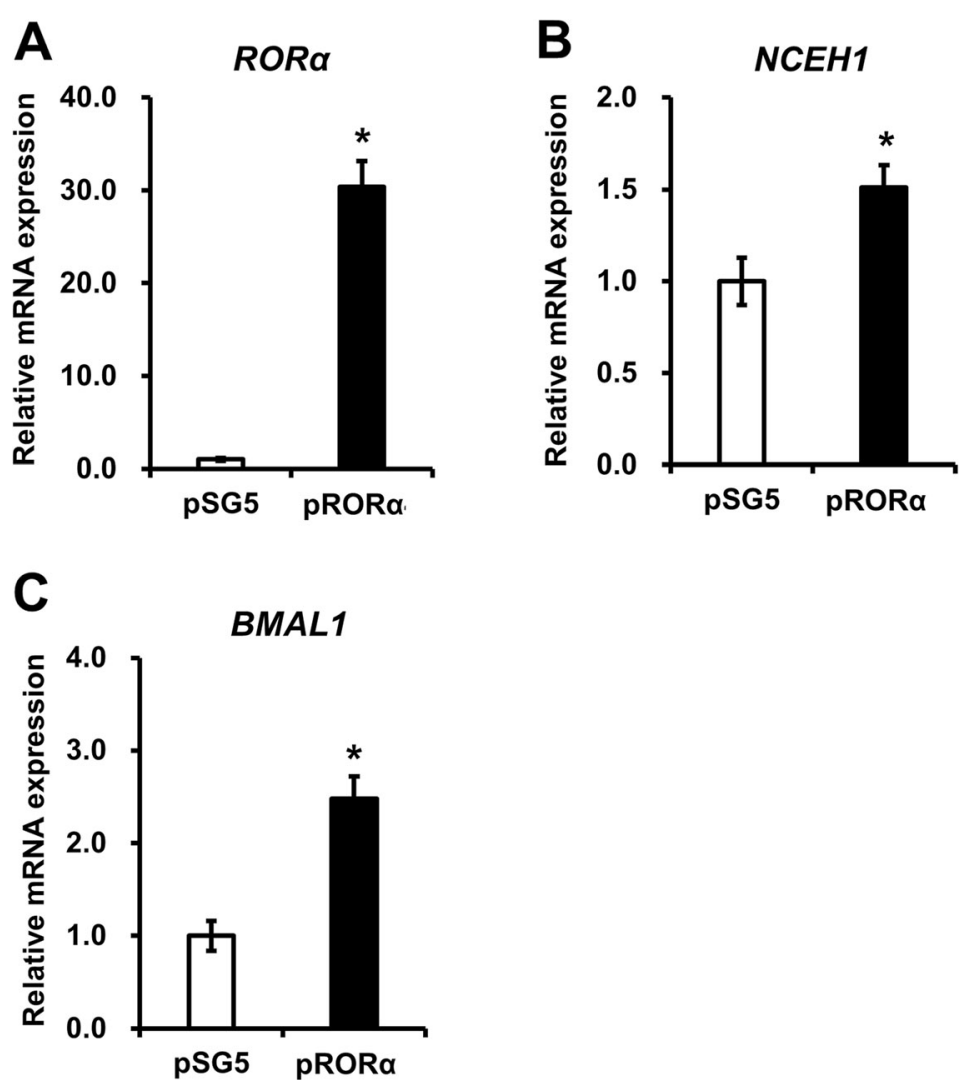

Fig. 4 Effects of RORa overexpression on NCEH1 expression. Transient overexpression of RORa was performed in HepG2 cells by transfecting cells with empty vector (pSG5) or with RORa expression vector (pRORa) for $48 \mathrm{~h}$. RORa (a), NCEH1 (b), and BMAL1 (c) gene expression levels were evaluated. The expression levels of RORa-target genes induced by pRORa are presented as the fold-change relative to those with pSG5. Data are means \pm standard errors $(n=4) .{ }^{*}, p<0.05$

that ROR $\alpha$ expression increased along with endogenous NCEH1 expression at both the mRNA and protein levels in THP1 macrophages.

\section{siRNA targeting of RORa reduces NCEH1 expression and lipid droplet formation}

To further investigate the effect of ROR $\alpha$ knockdown, we determined whether this could block the accumulation of lipid droplets through the downregulation of NCEH1 expression in HepG2 cells. Indeed, siRNA targeting the sequences around 258 and $1388 \mathrm{bp}$ downstream of the ROR $\alpha$ start codon suppressed NCEH1 transcription to $82 \%$, compared to $100 \%$ transcription in siGFP-transfected cells (Fig. 6a). Negative control siRNA (siGFP, targeting green fluorescent protein) did not affect NCEH1 transcription. No changes were observed in the expression of adipose triglyceride lipase (ATGL) and Lipase E (LIPE, Fig. 6b). The effects of siRNA transfection on cell viability were estimated by measuring lactate dehydrogenase (LDH) activity at $48 \mathrm{~h}$ after transfection with siROR $\alpha$. The results showed that LDH activities in siGFP- and siROR $\alpha$-transfected cells (95.6 and $89.3 \%$, respectively; Fig. 6c) were similar to those in untreated cells. Subsequently, cells were treated with oleic acid for $24 \mathrm{~h}$, and Oil Red $\mathrm{O}$ staining was performed. Notably, lipid droplet accumulation in cells transfected with siROR $\alpha$ was markedly increased compared with that in negative controls (fold-changes in cells transfected with siGFP at 100 and $400 \mathrm{nM}: 1.75$ and 1.69, respectively; Fig. $6 \mathrm{~d}$ and e).

\section{Effects of agonist-induced RORa activation on NCEH1 expression}

The effect of inducing NCEH1 expression by an ROR $\alpha$ agonist was examined. Analyses were performed in HepG2 cells treated for 48 or $72 \mathrm{~h}$ with $5 \mu \mathrm{M}$ SR1078 (ROR $\alpha$ agonist) or vehicle (DMSO). The mRNA levels of $\mathrm{ROR} \alpha$ were not altered in HepG2 cells treated with $5 \mu \mathrm{M}$ SR1078 (Fig. 7a). In contrast, NCEH1 expression levels were increased following treatment with an ROR $\alpha$ agonist (Fig. 7b). Additionally, the expression levels of BMAL1, as a positive control ROR $\alpha$-target gene, were 


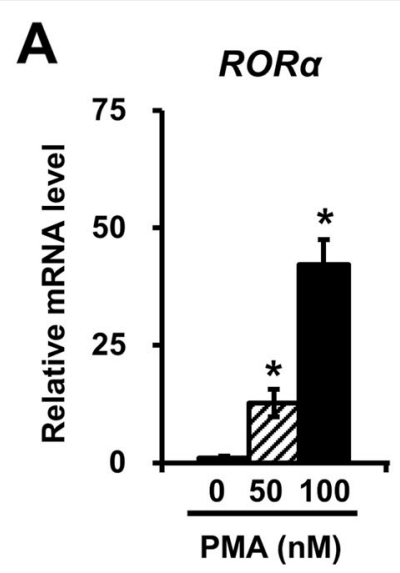

B

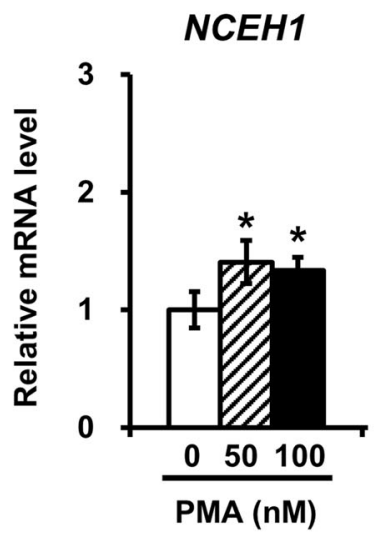

C

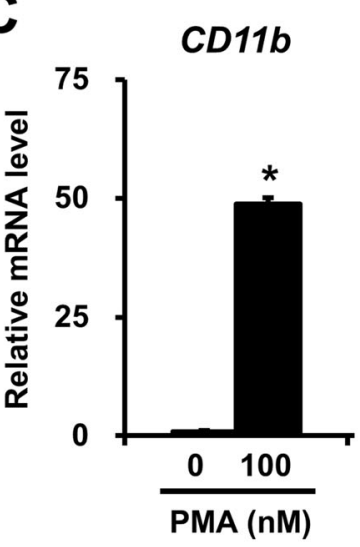

D

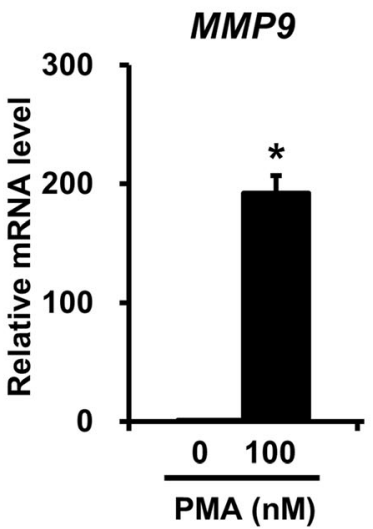

E

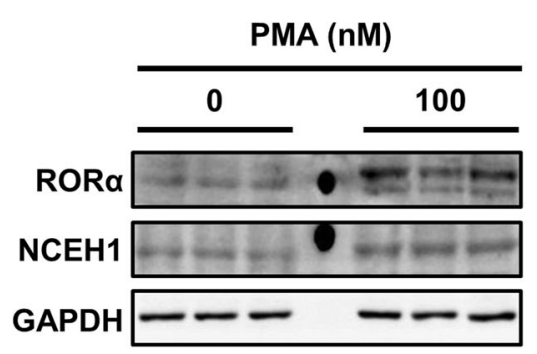

$\mathbf{F}$

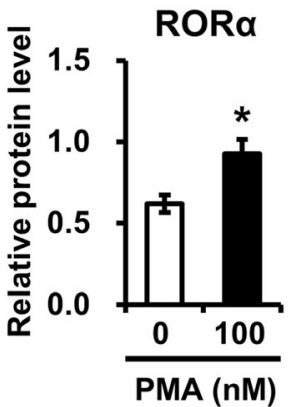

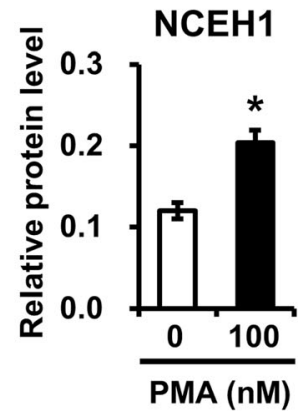

Fig. 5 NCEH1 expression is altered in a phorbol 12-myristate 13-acetate (PMA)-dependent manner during macrophage differentiation in THP1 cells. a-d THP1 cells were treated with $50 \mathrm{nM}$ (shaded bars), $100 \mathrm{nM}$ (closed bars), or no PMA (open bars) for $12 \mathrm{~h}$. mRNA expression of RORa (a), NCEH1 (b), CD11b (c), and MMP9 (d) was analyzed by qRT-PCR, and data were normalized to 185 rRNA levels. Data are means \pm standard errors $(n=4) .{ }^{*}, p<0.05$. e THP1 cells were treated with or without $100 \mathrm{nM}$ PMA for $24 \mathrm{~h}$. Protein expression of RORa, NCEH1, and GAPDH was analyzed by immunoblot analysis. $\mathbf{f}$ Summary of RORa and NCEH1 protein levels for each treatment. Data were normalized to GAPDH protein expression. Data are means \pm standard errors $(n=4) .{ }^{*}, p<0.05$

increased (Fig. 7c). In PMA-differentiated THP1 macrophages treated for $24 \mathrm{~h}$ with $5 \mu \mathrm{M}$ SR1078 (ROR $\alpha$ agonist) or vehicle (DMSO), the protein levels of NCEH1 were increased following treatment with an ROR $\alpha$ agonist (Fig. $7 \mathrm{~d}$ and e).
RORa activation inhibited lipid accumulation in macrophages induced by oxidized-LDL

In order to investigate the effect of ROR $\alpha$ activation on lipid accumulation, the intracellular cholesterol levels after ROR $\alpha$ overexpression, were measured in foam cells 
A

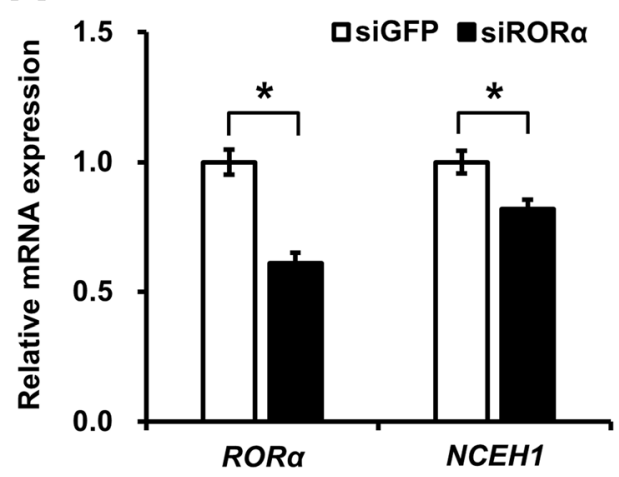

C

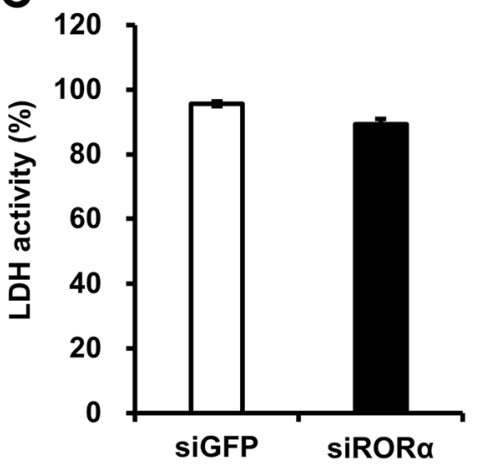

D
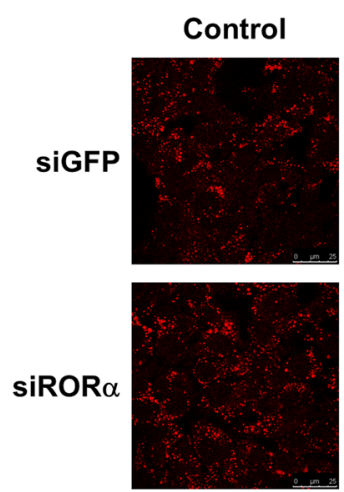

B

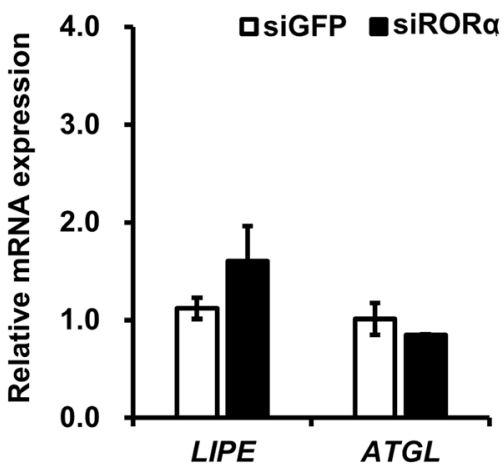

E

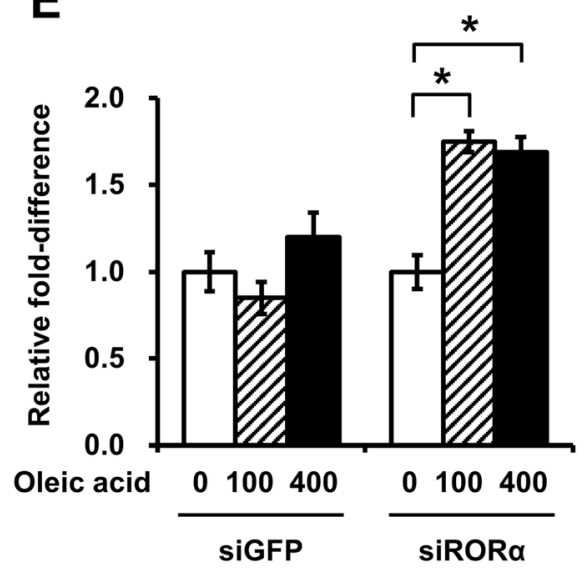

Fig. 6 Effects of RORa deficiency on NCEH1 and lipase expression and lipid droplet accumulation. a HepG2 cells were transfected with 50 nM SiRNA and analyzed by qRT-PCR to measure the expression of RORa and NCEH1. siRNAs targeting sequences in the RORa coding region (siRORa) were used and the resulting RORa and NCEH1 mRNA levels were measured. siRNA targeting green fluorescent protein was used as a negative control (siGFP). Data are means \pm standard errors $(n=3)$ and were normalized to $18 \mathrm{~S}$ rRNA levels. ${ }^{*}, p<0.05$. b Effects of siRNA transfection on the expression of adipose triglyceride lipase (ATGL) and Lipase E (LIPE). c Effects of siRNA transfection on cell viability were estimated by measuring lactate dehydrogenase (LDH) activity in the culture medium of siRNA-transfected cells. Data are means \pm standard errors $(n=4)$. ${ }^{*}, p<$ 0.05. d Lipid droplet accumulation was demonstrated by Oil Red O staining. At $48 \mathrm{~h}$ after transfection with siRNA targeting RORa or GFP, HepG2 cells were treated with $400 \mu \mathrm{M}$ oleic acid or DMSO (as a control) for $24 \mathrm{~h}$. e HepG2 cells were transfected with siRNA and treated with 0 , 100 , or $400 \mu \mathrm{M}$ oleic acid for $24 \mathrm{~h}$. Subsequently, the quantification of absorbance was performed to determine Oil Red $\mathrm{O}$ staining levels in the cells. Data are means \pm standard errors $(n=3) .{ }^{*}, p<0.05$ 

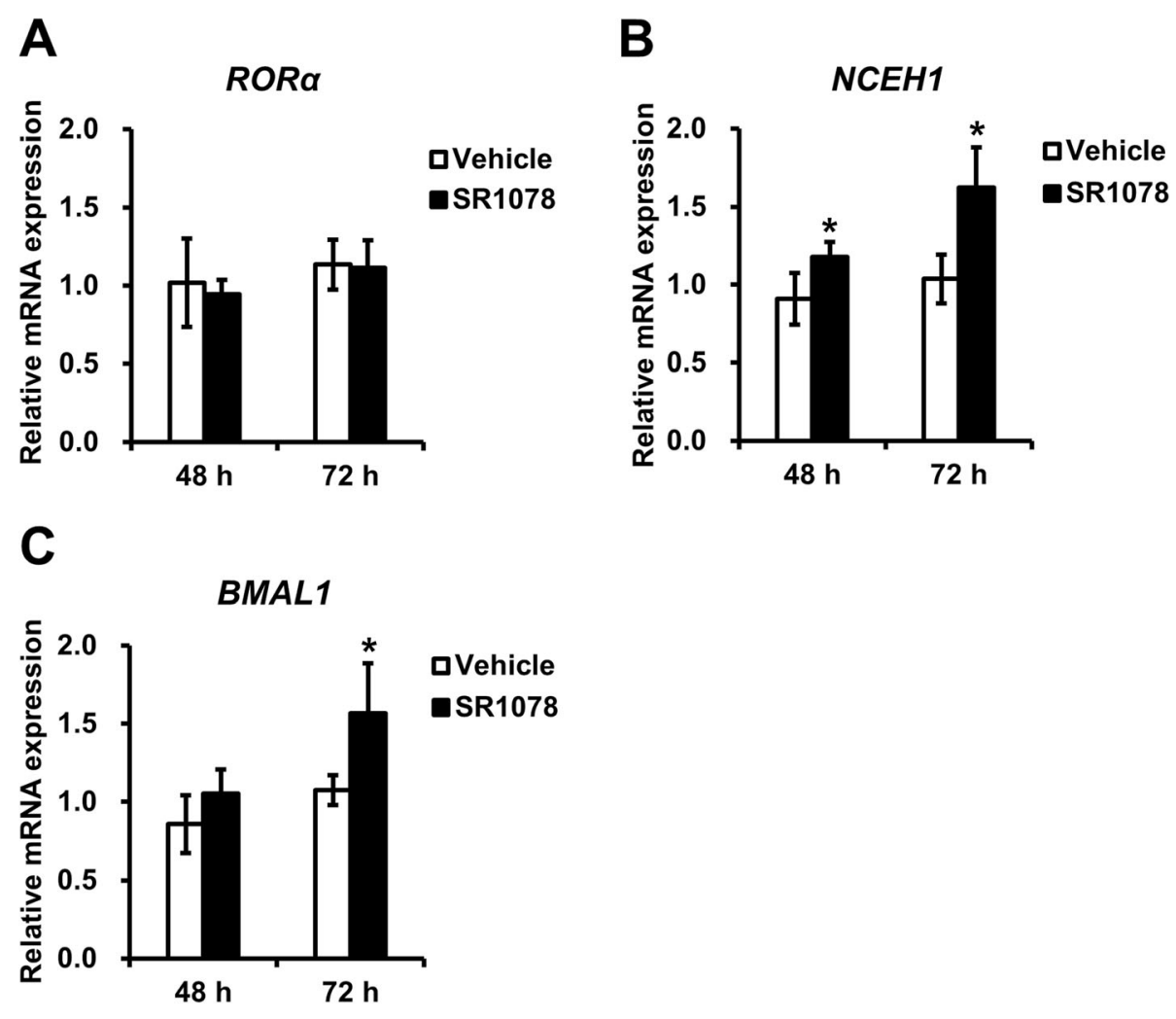

D

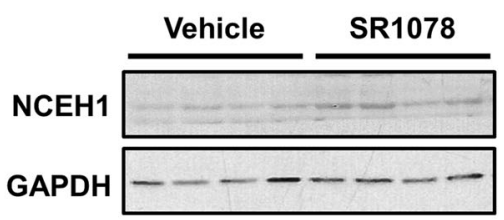

$\mathbf{E}$

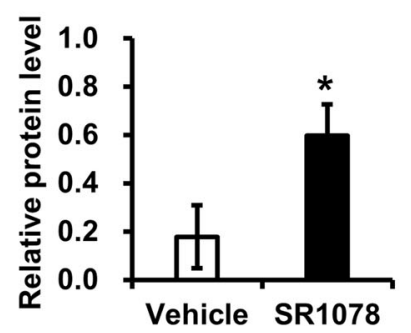

Fig. 7 Effects of agonist-induced RORa activation on NCEH1 expression. HepG2 cells expressing endogenous RORa were treated without (Vehicle, open bars) or with 5 MM SR1078 (closed bars) for 48 or 72 h, and RORa (a), NCEH1 (b), and BMAL1 (c) gene expression levels were evaluated. The expression levels of RORa-target genes stimulated by the RORa agonist are presented as the fold-change relative to those with the vehicle. Data are means \pm standard errors $(n=3) .{ }^{*}, p<0.05$. d THP1 cells were treated with $100 \mathrm{nM}$ phorbol 12-myristate 13-acetate (PMA) for $72 \mathrm{~h}$ and then treated without or with $5 \mu$ M SR1078 for 24 h. Protein expression of NCEH1 and GAPDH was analyzed by immunoblotting. e Summary of NCEH1 protein levels with each treatment. Data were normalized to GAPDH protein expression. Data are means \pm standard errors $(n=4) .{ }^{*}, p<0.05$

treated with oxidized low density lipoprotein (ox-LDL) in RAW264.2 macrophages. RAW264.7 cells transfected with the ROR $\alpha$ expression vector for $48 \mathrm{~h}$, were analyzed and the results were compared to that of the empty vector. ROR $\alpha$ overexpression resulted in a decrease in the total cholesterol levels (Fig. 8).

\section{Discussion}

NCEH1 is a key enzyme that suppresses lipid droplet formation by removing cholesterol in macrophage foam cells $[1,2]$. Downregulation of NCEH1 promotes atherosclerosis by increasing the generation of macrophage foam cells [3, 4]. Macrophage-specific overexpression of NCEH1 leads to a significant reduction in the atherosclerotic lesion area in $\mathrm{LDLR}^{-/-}$mice because of enhanced FC efflux and reverse cholesterol transport [3]. ROR $\alpha$-deficient mice harboring a natural deletion in the ligand-binding domain exhibit cerebellar ataxia, a phenotype also observed in sg/sg mice [15], which express mutated ROR $\alpha$ and present with dyslipidemia, excessive inflammation, immune abnormalities, vascular dysfunction, and diet-induced atherosclerosis [16-18]. In 


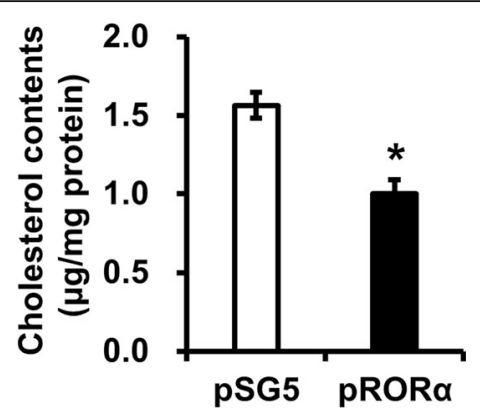

Fig. 8 Effects of RORa overexpression on intracellular cholesterol contents in macrophages. RAW264.7 cells were transfected with empty vector (PSG5) or RORa expression vector (pRORa), and cultured with $10 \mu \mathrm{g} / \mathrm{mL}$ of ox-LDL for the formation of macrophage foam cells. Cells were extracted and measured intracellular cholesterol content. Data are represented as means \pm standard errors $(n=3) .{ }^{*}, p<0.05$. Ox-LDL, oxidized low density lipoprotein

humans, ROR $\alpha$ is highly expressed in normal arterial cells. However, ROR $\alpha$ expression is significantly reduced in atherosclerotic plaques [39]. The ROR $\alpha$ expression level and the malignancy of arteriosclerosis may be closely related.

In this study, the results showed that the NCEH1 gene is a direct target of ROR $\alpha$ in macrophages and is related to lipid droplet regulation. First, a global search for ROREs as ROR $\alpha$-binding sites involved in transcriptional regulation within -1500 to +500 from the TSS of human genes in the DBTSS database [40] and by TFBIND [41] analysis as software for searching transcription factor binding sites on DNA sequences identified the promoter region of NCEH1 as a putative target of ROR $\alpha$. Therefore, in this study, the promoter region of NCEH1 was isolated and characterized. Using ENCODE data, two distal, conserved, putative ROREs were identified in the $5^{\prime}$ region of the NCEH1 gene containing the promoter and a highly conserved RGGTCA (R: A or G) half-site motif. One of the ROREs, RORE2, was located within a DNase I hypersensitivity site, and H3K27Ac ChIP-seq indicated transcriptional enhancement at RORE2, but not at RORE1. A comparison of the human RORE with those of rhesus monkeys, rats, and mice revealed that this element is highly conserved between humans and rhesus monkeys. However, low sequence conservation was observed with rats and mice, suggesting that this element might not have a major role in the transcriptional regulation of ROR $\alpha$ in these animals. The results also showed that ROR $\alpha$ binds this response element and that the receptor modestly stimulates expression. In addition, PMA-induced stimulation of NCEH1 expression was dependent on ROR $\alpha$ induction in macrophages, and the transient overexpression of ROR $\alpha$ induced NCEH1 transcription. Moreover, the suppression of $\mathrm{ROR} \alpha$ expression by siRNA significantly decreased
NCEH1 transcription and accumulated lipid droplet. Additionally, ROR $\alpha$ overexpression and ROR $\alpha$ agonisttreated cells showed an increase in the NCEH1 expression and a decrease in the intracellular cholesterol content in macrophages. Taken together, these data strongly indicated that NCEH1 is a direct target of ROR $\alpha$, defining potential new roles for ROR $\alpha$ in the inhibition of lipid droplet formation through NCEH1.

Macrophages from ROR $\alpha$-deficient sg/sg mice show the ability to accumulate lipids and therefore harbor large lipid droplets. Bone marrow-derived macrophages from $\mathrm{sg} / \mathrm{sg}$ mice exhibit significantly reduced mRNA and protein levels of cholesterol 25-hydroxylase (Ch25h) and deficiencies in phagocytosis. Ch25 produces 25-OHC from cholesterol; 25-OHC functions as an agonist for liver $\mathrm{X}$ receptor $\alpha(\mathrm{LXR} \alpha)$ and is an inverse agonist for $\mathrm{ROR} \alpha$, functioning through the transcriptional regulation of target genes [42, 43]. Recent work has also defined a role for LXRs in the regulation of gene expression in response to cellular lipid loading. ABCA1 and ABCG1, two members of the ATP-binding cassette $(A B C)$ family of transporter proteins, are highly induced in lipid-loaded macrophages [44, 45]. LXRs activate target genes by binding DNA sequences associated with target genes. LXRs then bind consensus elements (LXREs) as heterodimers with isoforms of retinoid X receptors. LXRE consists of two direct repeats of the consensus sequence AGGTCA separated by four nucleotides $[46,47]$. In contrast, $\mathrm{ROR} \alpha$ regulates target gene expression mainly by binding as monomers to promoter response elements, which typically consist of a consensus AGGTCA half-site preceded by an A/T-rich sequence [12]. The response elements on NCEH1 are not two direct repeats but are instead consensus ROREs involved in direct transcriptional regulation by $R O R \alpha$. ROR $\alpha$ has been shown to directly regulate hepatic expression of SREBP-1c and the reverse cholesterol transporters ABCA1 and ABCG1 [19]. Moreover, ROR $\alpha$ positively regulates APOA-I and APOC-III, suggesting a role for the receptor in lipid metabolism [20, 21] and lipid homeostasis [48, 49]. Additionally, the transcriptional activator SRC-2 functions as a coactivator with ROR $\alpha$ to modulate G6Pase [22] and PEPCK expression [23]. Thus, ROR $\alpha$ and LXR share many common target genes. In macrophages, ROR $\alpha$ and $25-\mathrm{OHC}$ crosstalk regulates lipid droplet homeostasis, whereas the absence of NCEH1 augments 25-OHC-induced endoplasmic reticulum stress and apoptosis [50, 51]. 25-OHC functions as an oxysterol to regulate ROR $\alpha$ activation and NCEH1 expression. Moreover, the treatment of liver macrophages with synthetic ROR $\alpha$ ligands was found to modulate nonalcoholic steatohepatitis (NASH); activation of ROR $\alpha$ by SR1078 [52] as an ROR $\alpha$ agonist results in protection against NASH and loss of ROR $\alpha$ function, 
whereas inhibition of ROR $\alpha$ function by SR3335 [25], an $\mathrm{ROR} \alpha$-selective inverse agonist, results in the progression of NASH [53]. Further pharmacological and pathophysiological studies are currently investigating the development of candidate ROR $\alpha$ ligands for various applications $[54,55]$.

In pharmacological therapies involving nuclear receptor ligands, increased activity of lipoprotein lipase (LPL) in response to various peroxisome proliferator-activated receptors (PPARs) might explain the hypotriglyceridemic effects of fibrates, thiazolindinediones, and fatty acids, which are known activators (and/or ligands) of the various PPARs. Treatment with compounds that preferentially activate PPAR $\alpha$, such as fenofibrate, induces LPL expression exclusively in the livers of rats. In addition, the antidiabetic thiazolidinedione, a high-affinity ligand for PPAR $\gamma$, has no effect on the liver but induces LPL expression in rat adipose tissues [56]. Moreover, endocrine therapy targeting the estrogen receptor (ER) is a standard of care for the treatment of postmenopausal women with ER-positive breast cancer. Given the dependence of these tumors on active ER signaling, the predominant treatment strategy has been to inhibit various aspects of this pathway, including directly antagonizing the ER with the use of selective ER modulators. Selective ER modulators have been used for the treatment of advanced breast cancer and are currently being evaluated for all stages of ER-positive disease [57]. Selective receptor modulators (SRMs) are receptor ligands that exhibit agonistic or antagonistic biocharacteristics in a cell- and tissue context-dependent manner. SRMinduced alterations in the conformation of the ligandbinding domains of nuclear receptors influences their abilities to interact with other proteins such as coactivators and corepressors [58]. In contrast, ROR $\alpha$ ligands might be able to control some ROR $\alpha$-target genes, although it is currently not possible to achieve pathological tissue-specific selectivity.

\section{Conclusions}

In summary, the data from this study suggested that human NCEH1 is a direct target of ROR $\alpha$, containing two functional response elements in the NCEH1 promoter region. Our results defined potential new roles for ROR $\alpha$ in the cholesterol metabolism of macrophages, possibly by regulating NCEH1 expression. NCEH1 activation, which leads to the removal of cholesterol esters in lipid droplets in macrophages, may be important for the suppression of arteriosclerosis. Additionally, preventing the accumulation of lipid droplets using agonists of ROR $\alpha$ is a possible new therapeutic approach. Improving our understanding of the interactions between ROR $\alpha$ and its ligands may facilitate the development of specific drugs for the treatment of inflammation, metabolic diseases, obesity, and atherosclerosis.

\section{Methods \\ Cell culture}

Human THP1 monocytic cells were used as a model for monocytes and were maintained in RPMI-1640 supplemented with $10 \%$ fetal bovine serum (FBS), $100 \mathrm{U} / \mathrm{mL}$ penicillin, and $100 \mu \mathrm{g} / \mathrm{mL}$ streptomycin. THP1 cells were differentiated into macrophages following treatment with $100 \mathrm{nM}$ PMA for 12 or $24 \mathrm{~h}$. RAW264.7 macrophages, HEK293 embryonic kidney cells and HepG2 hepatoma cells were maintained in Dulbecco's modified Eagle's medium (D-MEM) supplemented with $10 \% \mathrm{FBS}$, $100 \mathrm{U} / \mathrm{mL}$ penicillin, and $100 \mu \mathrm{g} / \mathrm{mL}$ streptomycin. All cell lines were obtained from the American Type Culture Collection (Manassas, VA, USA).

\section{EMSA}

EMSAs were performed as described previously [23]. The IкB probe was prepared by radiolabeling synthetic double-stranded DNA using $\left[\gamma_{-}{ }^{32} \mathrm{P}\right]$ ATP (Perkin-Elmer, Waltham, MA, USA). Unlabeled probe was used as a competitive inhibitor, and IKB, which contained a known RORE [33], was used as a positive competitive control. In this assay, $0.02 \mathrm{pmol}^{32} \mathrm{P}$-radiolabeled probe was incubated with $\mathrm{ROR} \alpha$ crude product from in vitro translation, along with 0.1 and $0.4 \mathrm{pmol}$ unlabeled DNA as wild-type and mutant NCEH1-RORE1 and -RORE2. Probe sequences are listed in Supplementary Table S1. For supershift assays, anti-ROR $\alpha$ antibodies (cat. no. sc28,612; Santa Cruz Biotechnology, Santa Cruz, CA, USA) or anti-EgrI antibodies (cat. no. sc-110; Santa Cruz Biotechnology) as a negative control were pre-incubated with the ROR $\alpha$ crude product prior to the addition of the oligonucleotide probe. Gel electrophoresis was conducted at $120 \mathrm{~V}$ using $4 \%$ native polyacrylamide gels and $0.5 \times$ TBE buffer. The autoradiograms were obtained and quantified using a Typhoon 9400 variable mode imager (GE Healthcare, Little Chalfont, UK).

\section{ChIP assays}

ChIP assays were performed using a OneDay ChIP Kit (Diagenode, Liege, Belgium). THP1 monocytes and differentiated macrophages were used as samples. Samples containing protein/chromatin complexes were incubated with antibodies specific for ROR $\alpha$ (cat. no. sc-28,612; Santa Cruz Biotechnology) or nonimmunized IgG as a negative control overnight at $4{ }^{\circ} \mathrm{C}$. Immunoprecipitated complexes were eluted with elution buffer (1\% sodium dodecyl sulfate [SDS], $50 \mathrm{mM}$ tris- $\mathrm{HCl}$ [pH 7.5], and 10 $\mathrm{mM}$ ethylenediaminetetraacetic acid). Sample DNA was purified and amplified by PCR using designed primers specific to the NCEH1 promoter region. Primer 
sequences are listed in Supplementary Table S1. The band intensities of PCR products were analyzed with a CS Analyzer (Atto, Tokyo, Japan). The relative binding intensity to ROREs was calculated by fixed quantitative PCR using a Light Cycler 480 SYBR Green I Master kit (Roche Diagnostics, Mannheim, Germany) in a Light Cycler 480 instrument (Roche).

\section{Luciferase reporters}

The luciferase reporter plasmids pRORE1 13 -wt, pRORE2x3-wt, pRORE1x3-mt, and pRORE2x3-mt containing triplet repeats of NCEH1-ROREs were constructed. Synthetic oligonucleotides corresponding to sense and antisense ROREs, as used for EMSA (Supplementary Table S1), were phosphorylated with T4 DNA polynucleotide kinase (Takara Bio, Shiga, Japan), mixed, and annealed. Each resulting double-stranded oligonucleotide was cloned into the SmaI site of the reporter vector PGVP2 (Nippon Gene, Tokyo, Japan) containing the SV40 promoter. Moreover, the human NCEH1 promoter [pNCEH1(-1689/+ 128)], from -1689 to +128 relative to the TSS, was amplified by PCR and inserted as a $\mathrm{KpnI} / \mathrm{MluI}$-fragment into the promoterless luciferase expression vector PGVB2 (Nippon Gene). The wildtype and mutant promoter sequences for RORE2 [pNCEH1 (- 140/+ 128)-wt and -mt] were generated by PCR using the pNCEH1 $(-1689 /+128)$ plasmid as a template. Briefly, the primer sets Promoter-RORE2-FWKpnI, Promoter-RORE2mt-FW-KpnI, and PromoterRV-MluI were synthesized to incorporate the desired mutation (Supplementary Table S1), and a continuous fragment was produced. This fragment was then cloned as a KpnI/MluI-fragment into PGVB2. All cloned plasmids were purified using a Qiagen Plasmid Mini Kit (Qiagen, Valencia, CA, USA). Inserts were confirmed by sequencing using PGVB2-FW and PGVB2-RV primers.

\section{Transfection and luciferase activity assay}

HEK293 cells were transfected using Lipofectamine 2000 (Life Technologies, Gaithersburg, MD, USA). Briefly, cells were seeded at $1 \times 10^{5}$ cells/well in D-MEM containing $10 \%$ fetal calf serum. After 1 day at $37^{\circ} \mathrm{C}$ and $5 \%$ $\mathrm{CO}_{2}$, cells in each well were transfected for $16 \mathrm{~h}$ with a mixture of $100 \mathrm{ng}$ various luciferase reporter plasmid, $100 \mathrm{ng}$ ROR $\alpha$ expression plasmid (pROR $\alpha$ ) or empty plasmid (pSG5), plus $100 \mathrm{ng} \beta$-galactosidase reporter plasmid (pSV-ßgal), which was used to normalize luciferase activity. Cells were grown for an additional 24-32 $\mathrm{h}$ in fresh medium and finally lysed. The lysate was assayed for luciferase activities using a PicaGene Luminescence Kit (Toyo Inc., Tokyo, Japan) with a Luminescencer-PSN AB-2200 (Atto). Data were collected from at least four independent experiments.

\section{Quantitative reverse transcription-PCR (qRT-PCR)}

THP1 cells were seeded at $1 \times 10^{5}$ cells/well in RPMI1640 supplemented with $10 \% \mathrm{FBS}, 100 \mathrm{U} / \mathrm{mL}$ penicillin, and $100 \mu \mathrm{g} / \mathrm{mL}$ streptomycin. After $24 \mathrm{~h}$ at $37^{\circ} \mathrm{C}$ and $5 \% \mathrm{CO}_{2}$, THP1 cells were differentiated into macrophages via treatment with $100 \mathrm{nM}$ PMA for $12 \mathrm{~h}$. In ROR $\alpha$ agonist-treated experiments, THP1 cells were differentiated into macrophages by treating them with $100 \mathrm{nM}$ PMA for $72 \mathrm{~h}$ and were then treated with $5 \mu \mathrm{M}$ SR1078, an ROR $\alpha$ agonist, for $24 \mathrm{~h}$. HepG2 cells were seeded at $1 \times 10^{5}$ cells/well in D-MEM supplemented with $10 \%$ FBS, $100 \mathrm{U} / \mathrm{mL}$ penicillin, and $100 \mu \mathrm{g} / \mathrm{mL}$ streptomycin. After $24 \mathrm{~h}$ at $37^{\circ} \mathrm{C}$ and $5 \%$ $\mathrm{CO}_{2}$, HepG2 cells were induced by treatment with $5 \mu \mathrm{M}$ SR1078 as an ROR $\alpha$ agonist for 48 or $72 \mathrm{~h}$. qRTPCR using a SYBR green reaction was performed as described previously [23]. ROR $\alpha$ and NCEH1 expression levels were measured, with CD11b and MMP9 as positive controls of macrophage-specific genes and BMAL1 as a positive control ROR $\alpha$-target genes. Additionally, the expression of ATGL and LIPE was measured to indicate the expression of genes involved in lipid hydrolysis. These genes were quantified using specific primer sets with the following protocol: $40 \mathrm{cy}$ cles at $95^{\circ} \mathrm{C}$ for $10 \mathrm{~s}, 56^{\circ} \mathrm{C}$ for $10 \mathrm{~s}$, and $72{ }^{\circ} \mathrm{C}$ for $15 \mathrm{~s}$, following initial denaturation at $95^{\circ} \mathrm{C}$ for $2 \mathrm{~min}$. The $18 \mathrm{~S}$ rRNA gene was used as an internal control. Primer sequences for all genes are listed in Supplementary Table S1. Data were collected from at least three independent experiments.

\section{Western blotting analysis}

Cells were washed in phosphate-buffered saline (PBS) and homogenized in lysis buffer containing $50 \mathrm{mM}$ Tris$\mathrm{HCl}$ ( $\mathrm{pH} 7.0$ ), $200 \mathrm{mM}$ sucrose, $1 \mathrm{mM}$ ethylenediaminetetraacetic acid, $1 \mu \mathrm{g} / \mathrm{mL}$ leupeptin, $1 \mu \mathrm{g} / \mathrm{mL}$ pepstatin, $0.5 \mathrm{mM}$ phenylmethylsulfonyl fluoride, and 1\% SDS on ice. The samples were subjected to SDS-polyacrylamide gel electrophoresis on $12 \%$ gels. Proteins on the SDSslab gel were transferred to Immobilon-P membranes (Merck Millipore, Billerica, MA, USA) by electrophoresis. Detection of proteins was performed using rabbit anti-ROR $\alpha$ (cat. no. sc-28,612; Santa Cruz Biotechnology), anti-NCEH1 (cat. no. PA5-50285; Thermo Fisher Scientific, Waltham, MA, USA), and anti-glyceraldehyde 3-phosphate dehydrogenase (GAPDH) antibodies (cat. no. sc-20,357; Santa Cruz Biotechnology). Subsequently, the membranes were rinsed and incubated with horseradish peroxidase-conjugated goat anti-rabbit IgG. Bound antibodies were detected with enhanced chemiluminescence western blotting detection regents (GE Healthcare) according to the manufacturer's instructions. The band intensities were analyzed with a CS Analyzer (Atto). 


\section{Overexpression analysis}

HEK293 cells were transfected using Lipofectamine 2000 (Life Technologies). Briefly, cells were seeded at $1 \times 10^{5}$ cells/well in D-MEM containing $10 \%$ fetal calf serum. After 1 day at $37{ }^{\circ} \mathrm{C}$ and $5 \% \mathrm{CO}_{2}$, cells in each well were transfected for $16 \mathrm{~h}$ with a mixture of 500 ng ROR $\alpha$ expression plasmid (pROR $\alpha$ ) or empty plasmid (pSG5). Cells were grown for an additional $48 \mathrm{~h}$ in fresh medium and lysed. The lysate was assayed for qRT-PCR using a SYBR green reaction performed as described previously [23].

\section{siRNA experiments}

siRNAs targeting different sequences in ROR $\alpha$ (siRORa258 and siRORa-1388) were generated using an in vitro transcription T7 kit (Takara Bio). siRNA against green fluorescent protein (siGFP) was used as a negative control. siRNA oligonucleotide sequences are listed in Supplementary Table S1. HepG2 cells were seeded in 24well plates at $0.5 \times 10^{5}$ cells/well and transfected using Lipofectamine 2000 (Life Technologies) with siRNA the following day. Cells were harvested $48 \mathrm{~h}$ after transfection, and total RNA was prepared using ISOGEN reagent (Wako Pure Chemical, Osaka, Japan). ROR $\alpha$ and NCEH1 levels were quantified by qRT-PCR as described above. The effects of siRNA transfection on cell viability were estimated by measuring LDH activity using a Cytotoxicity Detection Kit PLUS (Roche), following the manufacturer's protocol. Data were collected from at least three independent experiments.

\section{Lipid droplet assays}

Oil Red O stock solution was prepared in isopropanol $(0.3 \mathrm{~g} / 100 \mathrm{~mL})$. siRNA-transfected HepG2 cells were fixed with $4 \%$ paraformaldehyde for $10 \mathrm{~min}$ and washed with PBS. The cells were then soaked in 60\% Oil Red O stock solution diluted with distilled water for $20 \mathrm{~min}$, and stained cells were washed with PBS. Cells were observed using a Leica TCS-SPE DMI4000B microscope (Leica Microsystems, Wetzlar, Germany). Moreover, lipid droplet accumulation was measured by determining the absorbance at $510 \mathrm{~nm}$ in isopropanol-eluted samples from stained cells. Normalization was carried out according to the protein concentrations determined using a protein assay kit (Bio-Rad Laboratories, Hercules, CA, USA).

\section{Cholesterol content measurement}

RAW264.7 cells were seeded at $6 \times 10^{5}$ cells/well into 6well plates in DMEM supplemented with $10 \%$ FBS. After $24 \mathrm{~h}$ at $37^{\circ} \mathrm{C}$ and $5 \% \mathrm{CO}_{2}$, RAW264.7 cells were transfected with $1 \mu \mathrm{g}$ pROR $\alpha$ or pSG5 vector for $24 \mathrm{~h}$. Cells were cultured for $24 \mathrm{~h}$ with $10 \mu \mathrm{g} / \mathrm{mL}$ ox-LDL (Thermo Fisher Scientific) for the lipid droplet formation.
Subsequently, cells were extracted in a lysis buffer and centrifuged at $1000 \mathrm{~g}$ for $10 \mathrm{~min}$. The supernatant was mixed with Folch extract (chloroform-methanol, 2:1), and kept on a shaker for $10 \mathrm{~min}$. Mixture was centrifuged at $3000 \mathrm{~g}$ for $10 \mathrm{~min}$, and the supernatant was evaporated by drying up and then dissolved in $200 \mu \mathrm{L}$ of isopropyl alcohol containing 1\% Triton X-100. Total cholesterol contents of free- and ester-types of intracellular cholesterol were measured using Cholesterol E-test Wako (Wako Pure Chemical). Cholesterol levels were normalized to the protein content.

\section{Statistical analysis}

All data are expressed as means \pm standard errors unless otherwise stated. Comparisons between two groups were made with unpaired Student's t-tests. In all cases, results with $P$ values of less than 0.05 were considered significant.

\section{Supplementary information}

Supplementary information accompanies this paper at https://doi.org/10. 1186/s12860-020-00276-z.

\begin{abstract}
Additional file 1: Table S1. Primers used in this study.
Additional file 2. Supplementary figure of Chromatin immunoprecipitation (ChIP) assays (Fig. 2C). ChIP assays were performed using chromatin isolated from human monocytes and differentiated macrophages treated with $100 \mathrm{nM}$ phorbol 12-myristate 13-acetate (PMA) for $24 \mathrm{~h}$. Crosslinked cell lysates were immunoprecipitated with rabbit lgG (lgG) or polyclonal anti-RORa-specific antibodies (RORa). DNA precipitates were isolated and then subjected to PCR using primer pairs covering either RORE1 (fragment size, 253 bp) or RORE2 (fragment size, 247 bp) of the NCEH1 promoter region. Control PCR was performed with nonimmunoprecipitated genomic DNA (input). M, size marker.

Additional file 3. Supplementary figure of immunoblot analysis (Fig. 5e). THP1 cells were treated with or without $100 \mathrm{nM}$ phorbol 12-myristate 13-acetate (PMA) for $24 \mathrm{~h}$. Protein expression of RORa, NCEH1, and GAPDH was analyzed by immunoblot analysis. Molecular weight of RORa, NCEH1 and GAPDH are 60, 48 and $37 \mathrm{kDa}$, respectively.

Additional file 4. Supplementary figure of immunoblot analysis (Fig 7d). THP1 cells were treated with $100 \mathrm{nM}$ phorbol 12-myristate 13-acetate (PMA) for $72 \mathrm{~h}$ and then treated without or with $5 \mu \mathrm{M}$ SR1078 for $24 \mathrm{~h}$. Protein expression of NCEH1 and GAPDH was analyzed by immunoblotting. Molecular weight of NCEH1 and GAPDH are 48 and $37 \mathrm{kDa}$, respectively.
\end{abstract}

\section{Abbreviations}

RORa: Retinoic acid receptor-related orphan receptor a; ROREs: RORa response elements; NCEH1: Neutral cholesterol ester hydrolase 1; CE: Cholesterol ester; FC: Free cholesterol; LDLR: Low-density lipoprotein receptor; PGC-1a: Peroxisome proliferator-activated receptor $\gamma$ coactivator 1a; TSS: Transcription start site; 24-OHC: 24-hydroxycholesterol; APOA: Apolipoprotein A; G6Pase: Glucose 6-phosphatase; PEPCK: Phosphoenolpyruvate carboxykinase; CLDND1: Claudin domain containing 1; PMA: Phorbol 12-myristate 13-acetate; ATGL: Adipose triglyceride lipase; LIPE: Lipase E; LDH: Lactate dehydrogenase; oxLDL: oxidized low density lipoprotein; NASH: Nonalcoholic steatohepatitis; LXRa: Liver X receptor a; PPARs: Peroxisome proliferator-activated receptors; ER: Estrogen receptor; SRMs: Selective receptor modulators; EMSA: Electrophoretic mobility shift assay; ChIP-PCR: Chromatin immunoprecipitation polymerase chain reaction; qRT-PCR: quantitative reverse transcription-PCR 


\section{Acknowledgements}

We thank Arisa Uda, Sou Kobayashi and Yuto Miyamoto from Fukuyama University for technical assistance. This work was supported by a grant from NIG-JOINT (grant no. 73A2018) to H. Matsuoka. We are grateful to Dr. Kazuho Ikeo (Center for Information Biology, National Institute of Genetics) for advice on selection of the putative RORa target genes and for helpful discussions.

\section{Authors' contributions}

HM shared responsibility for the writing of the manuscript with AM. All authors were responsible for the study conception and design. HM, RT, MK, $\mathrm{YH}, \mathrm{KM}, \mathrm{KS}, \mathrm{AO}$, JK and AS carried out the experiments. HM, and RT, MK, KM and KS analyzed the data. All authors read and approved the final manuscript.

\section{Funding}

This work was supported by a Fukuyama University Grant for Academic Research Projects (grant no. GARP 2018-103). The funding bodies played no role in the design of the study and collection, analysis, and interpretation of data and in writing the manuscript.

\section{Availability of data and materials}

All data generated or analyzed during this study are included in this article and its supplementary information files.

\section{Ethics approval and consent to participate}

Not applicable.

\section{Consent for publication}

Not applicable.

\section{Competing interests}

The authors declare that they have no competing interests.

\section{Author details}

${ }^{1}$ Laboratory of Genome Function and Pathophysiology, Faculty of Pharmacy and Pharmaceutical Sciences, Fukuyama University, Fukuyama, Hiroshima 729-0292, Japan. 'Laboratory of Biochemistry, Faculty of Pharmacy and Pharmaceutical Sciences, Fukuyama University, Fukuyama, Hiroshima 729-0292, Japan

Received: 17 July 2019 Accepted: 8 April 2020

Published online: 22 April 2020

\section{References}

1. Okazaki H, Igarashi M, Nishi M, Sekiya M, Tajima M, Takase S, et al. Identification of neutral cholesterol ester hydrolase, a key enzyme removing cholesterol from macrophages. J Biol Chem. 2008;283:33357-64..

2. Sekiya M, Osuga J, Igarashi M, Okazaki H, Ishibashi S. The role of neutral cholesterol ester hydrolysis in macrophage foam cells. J Atheroscler Thromb. 2011:18:359-64.

3. Sekiya M, Osuga J, Nagashima S, Ohshiro T, Igarashi M, Okazaki H, et al. Ablation of neutral cholesterol ester hydrolase 1 accelerates atherosclerosis. Cell Metab. 2009;10:219-28.

4. Igarashi M, Osuga J, Uozaki H, Sekiya M, Nagashima S, Takahashi M, et al. The critical role of neutral cholesterol ester hydrolase 1 in cholesterol removal from human macrophages. Circ Res. 2010;107:1387-95.

5. Yuan Y, Li P, Ye J. Lipid homeostasis and the formation of macrophagederived foam cells in atherosclerosis. Protein Cell. 2012;3:173-81.

6. Ouimet M, Marcel YL. Regulation of lipid droplet cholesterol efflux from macrophage foam cells. Arterioscler Thromb Vasc Biol. 2012;32:575-81.

7. Napolitano M, Avella M, Botham KM, Bravo E. Chylomicron remnant induction of lipid accumulation in $\mathbf{J 7 7 4}$ macrophages is associated with upregulation of triacylglycerol synthesis which is not dependent on oxidation of the particles. Biochim Biophys Acta. 1631;2003:255-64.

8. Sakai K, Igarashi M, Yamamuro D, Ohshiro T, Nagashima S, Takahashi M, et al. Critical role of neutral cholesteryl ester hydrolase 1 in cholesteryl ester hydrolysis in murine macrophages. J Lipid Res. 2014;55:2033-40.

9. Yamashita M, Tamasawa N, Matsuki K, Tanabe J, Murakami H, Matsui J, et al. Insulin suppresses HDL-mediated cholesterol efflux from macrophages through inhibition of neutral cholesteryl ester hydrolase and ATP-binding cassette transporter G1 expressions. J Atheroscler Thromb. 2010;17:1183-9.
10. McLaren JE, Michael DR, Salter RC, Ashlin TG, Calder CJ, Miller AM, et al. IL33 reduces macrophage foam cell formation. J Immunol. 2010;185:1222-9.

11. Lucas EK, Dougherty SE, McMeekin LJ, Reid CS, Dobrunz LE, West AB, et al. PGC-1a provides a transcriptional framework for synchronous neurotransmitter release from parvalbumin-positive interneurons. J Neurosci. 2014;34:14375-87.

12. Giguère $V$, Tini $M$, Flock $G$, Ong E, Evans RM, Otulakowski G. Isoformspecific amino-terminal domains dictate DNA-binding promoters of ROR alpha, a novel family of orphan hormone nuclear receptors. Genes Dev. 1994;8:538-53.

13. Solt LA, Burris TP. Action of RORs and their ligands in (patho)physiology Trends Endocrinol Metab. 2012;23:619-27.

14. Kojetin DJ, Burris TP. REV-ERB and ROR nuclear receptors as drug targets. Nat Rev Drug Discov. 2014;13:197-216.

15. Harding HP, Atkins GB, Jaffe AB, Seo WJ, Lazar MA. Transcriptional activation and repression by RORalpha, an orphan nuclear receptor required for cerebellar development. Mol Endocrinol. 1997:11:1737-46.

16. Jarvis Cl, Staels B, Brugg B, Lemaigre-Dubreuil Y, Tedgui A, Mariani J. Age-related phenotypes in the staggerer mouse expand the RORalpha nuclear receptor's role beyond the cerebellum. Mol Cell Endocrinol. 2002;186:1-5.

17. Mamontova A, Séguret-Macé S, Esposito B, Chaniale C, Bouly M, DelhayeBouchaud N, et al. Severe atherosclerosis and hypoalphalipoproteinemia in the staggerer mouse, a mutant of the nuclear receptor RORalpha. Circulation. 1998:98:2738-43.

18. Tuong ZK, Lau P, Yeo JC, Pearen MA, Wall AA, Stanley AC, et al. Disruption of Rora1 and cholesterol 25-hydroxylase expression attenuates phagocytosis in male Rora sg/sg mice. Endocrinology. 2013;154:140-9.

19. Lau P, Fitzsimmons RL, Raichur S, Wang SC, Lechtken A, Muscat GE. The orphan nuclear receptor, RORalpha, regulates gene expression that controls lipid metabolism: staggerer (SG/SG) mice are resistant to diet-induced obesity. J Biol Chem. 2008:283:18411-21.

20. Vu-Dac N, Gervois P, Grötzinger T, De Vos P, Schoonjans K, Fruchart JC, et al Transcriptional regulation of apolipoprotein A-I gene expression by the nuclear receptor RORalpha. J Biol Chem. 1997;272:22401-4.

21. Raspé E, Duez H, Gervois P, Fiévet C, Fruchart JC, Besnard S, et al. Transcriptional regulation of apolipoprotein C-III gene expression by the orphan nuclear receptor RORalpha. J Biol Chem. 2001;276:2865-71.

22. Chopra AR, Louet JF, Saha P, An J, Demayo F, Xu J, et al. Absence of the SRC-2 coactivator results in a glycogenopathy resembling Von Gierke's disease. Science. 2008;322:1395-9.

23. Matsuoka H, Shima A, Kuramoto D, Kikumoto D, Matsui T, Michihara A. Phosphoenolpyruvate Carboxykinase, a key enzyme that controls blood glucose, is a target of retinoic acid receptor-related Orphan Receptor a. PLoS One. 2015;10:e0137955.

24. Kadiri S, Monnier C, Ganbold M, Ledent T, Capeau J, Anoine B. The nuclear retinoid-related orphan receptor regulates adipose tissue glyceroneogenesis in addition to hepatic gluconeogenesis. Am J Physiol Endocrinol Metab. 2015;309:E105-14

25. Kumar N, Kojetin DJ, Solt LA, Kumar KG, Nuhant P, Duckett DR, et al. Identification of SR3335 (ML-176): a synthetic RORa selective inverse agonist. ACS Chem Biol. 2011;6:218-22.

26. Yin L, Wu N, Curtin JC, Qatanani M, Szwergold NR, Reid RA, et al. Reverbalpha, a heme sensor that coordinates metabolic and circadian pathways. Science. 2007:318:1786-9.

27. Grant D, Yin L, Collins JL, Parks DJ, Orband-Miller LA, Wisely GB, et al. GSK4112, a small molecule chemical probe for the cell biology of the nuclear heme receptor rev-erba. ACS Chem Biol. 2010;5:925-32.

28. Kojetin D, Wang Y, Kamenecka TM, Burris TP. Identification of SR8278, a synthetic antagonist of the nuclear heme receptor REV-ERB. ACS Chem Biol. 2011;6:131-4

29. Matsuoka H, Shima A, Uda A, Ezaki H, Michihara A. The retinoic acid receptor-related orphan receptor a positively regulates tight junction protein claudin domain-containing 1 mRNA expression in human brain endothelial cells. J Biochem. 2017;161:441-50.

30. Matsuoka H, Tamura A, Kinehara M, Shima A, Uda A, Tahara $H$, et al. Levels of tight junction protein CLDND1 are regulated by microRNA-124 in the cerebellum of stroke-prone spontaneously hypertensive rats. Biochem Biophys Res Commun. 2018;498:817-23.

31. Ohnishi M, Ochiai $H$, Matsuoka K, Akagi M, Nakayama $Y$, Shima A, et al. Claudin domain containing 1 contributing to endothelial cell adhesion 
decreases in presence of cerebellar hemorrhage. J Neurosci Res. 2017;95: 2051-8.

32. Nejati Moharrami N, Bjørkøy Tande E, Ryan L, Espevik T, Boyartchuk V. RORa controls inflammatory state of human macrophages. PLoS One. 2018;13: e0207374.

33. Delerive $\mathrm{P}$, Monté $\mathrm{D}$, Dubois $\mathrm{G}$, Trottein $\mathrm{F}$, Fruchart-Najib J, Mariani J, et al. The orphan nuclear receptor ROR alpha is a negative regulator of the inflammatory response. EMBO Rep. 2001;2:42-8.

34. Nolan GP, Ghosh S, Liou HC, Tempst P, Baltimore D. DNA binding and I kappa B inhibition of the cloned p65 subunit of NF-kappa B, a rel-related polypeptide. Cell. 1991;64:961-9.

35. Jetten AM, Kurebayashi S, Ueda E. The ROR nuclear orphan receptor subfamily: critical regulators of multiple biological processes. Prog Nucleic Acid Res Mol Biol. 2001;69:205-47.

36. Jetten AM. Retinoid-related orphan receptors (RORs): critical roles in development, immunity, circadian rhythm, and cellular metabolism. Nucl Recept Signal. 2009;7:e003.

37. Wasserman WW, Sandelin A. Applied bioinformatics for the identification of regulatory elements. Nat Rev Genet. 2004;5:276-87.

38. Kent WJ, Sugnet CW, Furey TS, Roskin KM, Pringle TH, Zahler AM, et al. The human genome browser at UCSC. Genome Res. 2002;12:996-1006.

39. Besnard S, Heymes C, Merval R, Rodriguez M, Galizzi JP, Boutin JA, et al. Expression and regulation of the nuclear receptor RORalpha in human vascular cells. FEBS Lett. 2002;511:36-40.

40. Yamashita R, Wakaguri H, Sugano S, Suzuki Y, Nakai K. DBTSS provides a tissue specific dynamic view of transcription start sites. Nucleic Acids Res. 2010;38:D98-104.

41. Tsunoda T, Takagi T. Estimating transcription factor bindability on DNA. Bioinformatics. 1999;15:622-30.

42. Janowski BA, Willy PJ, Devi TR, Falck JR, Mangelsdorf DJ. An oxysterol signalling pathway mediated by the nuclear receptor LXR alpha. Nature. 1996:383:728-31

43. Edwards PA, Kennedy MA, Mak PA. LXRs; oxysterol-activated nuclear receptors that regulate genes controlling lipid homeostasis. Vasc Pharmacol. 2002;38:249-56.

44. Lehmann JM, Kliewer SA, Moore LB, Smith-Oliver TA, Oliver BB, Su JL, et al. Activation of the nuclear receptor LXR by oxysterols defines a new hormone response pathway. J Biol Chem. 1997:272:3137-40.

45. Langmann T, Klucken J, Reil M, Liebisch G, Luciani MF, Chimini G, et al. Molecular cloning of the human ATP-binding cassette transporter 1 (hABC1): evidence for sterol-dependent regulation in macrophages. Biochem Biophys Res Commun. 1999;257:29-33.

46. Venkateswaran A, Laffitte BA, Joseph SB, Mak PA, Wilpitz DC, Edwards PA, et al. Control of cellular cholesterol efflux by the nuclear oxysterol receptor LXR alpha. Proc Natl Acad Sci U S A. 2000;97:12097-102.

47. Repa JJ, Turley SD, Lobaccaro JA, Medina J, Li L, Lustig K, et al. Regulation of absorption and ABC1-mediated efflux of cholesterol by RXR heterodimers. Science. 2000;289:1524-9.

48. Boukhtouche F, Mariani J, Tedgui A. The "CholesteROR" protective pathway in the vascular system. Arterioscler Thromb Vasc Biol. 2004;24:637-43.

49. Fitzsimmons RL, Lau P, Muscat GE. Retinoid-related orphan receptor alpha and the regulation of lipid homeostasis. J Steroid Biochem Mol Biol. 2012; 130:159-68.

50. Sekiya M, Yamamuro D, Ohshiro T, Honda A, Takahashi M, Kumagai M, et al. Absence of Nceh1 augments 25-hydroxycholesterol-induced ER stress and apoptosis in macrophages. J Lipid Res. 2014;55:2082-92.

51. Tuong ZK, Lau P, Du X, Condon ND, Goode JM, Oh TG, et al. RORa and 25Hydroxycholesterol crosstalk regulates lipid droplet homeostasis in macrophages. PLoS One. 2016;11:e0147179.

52. Wang $\mathrm{Y}$, Kumar N, Nuhant $\mathrm{P}$, Cameron MD, Istrate MA, Roush WR, et al. Identification of SR1078, a synthetic agonist for the orphan nuclear receptors RORa and RORY. ACS Chem Biol. 2010;5:1029-34.

53. Han YH, Kim HJ, Na H, Nam MW, Kim JY, Kim JS, et al. RORa induces KLF4mediated M2 polarization in the liver macrophages that protect against nonalcoholic Steatohepatitis. Cell Rep. 2017;20:124-35.

54. Dubernet $\mathrm{M}$, et al. Identification of new nonsteroidal RORa ligands; related structure-activity relationships and docking studies. ACS Med Chem Lett. 2013;4:504-8.

55. Billon C, Sitaula S, Burris TP. Inhibition of RORa/y suppresses atherosclerosis via inhibition of both cholesterol absorption and inflammation. Mol Metab. 2016;5:997-1005
56. Schoonjans K, et al. PPARalpha and PPARgamma activators direct a distinct tissue-specific transcriptional response via a PPRE in the lipoprotein lipase gene. EMBO J. 1996;15:5336-48.

57. Patel HK, Bihani T. Selective estrogen receptor modulators (SERMs) and selective estrogen receptor degraders (SERDs) in cancer treatment. Pharmacol Ther. 2018;186:1-24.

58. Smith $\mathrm{CL}, \mathrm{O}$ 'Malley BW. Coregulator function: a key to understanding tissue specificity of selective receptor modulators. Endocr Rev. 2004;25:45-71.

\section{Publisher's Note}

Springer Nature remains neutral with regard to jurisdictional claims in published maps and institutional affiliations.
Ready to submit your research? Choose BMC and benefit from:

- fast, convenient online submission

- thorough peer review by experienced researchers in your field

- rapid publication on acceptance

- support for research data, including large and complex data types

- gold Open Access which fosters wider collaboration and increased citations

- maximum visibility for your research: over $100 \mathrm{M}$ website views per year

At BMC, research is always in progress.

Learn more biomedcentral.com/submissions 